\title{
EXPERIENCE WITH THE FIRST INTERNET-BASED COURSE AT THE FACULTY OF MEDICINE, UNIVERSITY OF SÃO PAULO
}

\author{
Maurício de Maio and Marcus Castro Ferreira
}

RHCFAP/3039

MAIO M de et al. - Experience with the first Internet-based course at the Faculty of Medicine, University of São Paulo. Rev. Hosp. Clín. Fac. Med. S. Paulo 56(3):69-74, 2001.

Purpose: The Internet expands the range and flexibility of teaching options and enhances the ability to process the everincreasing volume of medical knowledge. The aim of this study is to describe and discuss our experience with transforming a traditional medical training course into an Internet-based course.

Method: Sixty-nine students were enrolled for a one-month course. They answered pre- and post-course questionnaires and took a multiple-choice test to evaluate the acquired knowledge.

Results: Students reported that the primary value for them of this Internet-based course was that they could choose the time of their class attendance (67\%). The vast majority (94\%) had a private computer and were used to visiting the Internet (75\%) before the course. During the course, visits were mainly during the weekends (35\%) and on the last week before the test (29\%). Thirty-one percent reported that they could learn by reading only from the computer screen, without the necessity of printed material. Students were satisfied with this teaching method as evidenced by the $89 \%$ who reported enjoying the experience and the $88 \%$ who said they would enroll for another course via the Internet. The most positive aspect was freedom of scheduling, and the most negative was the lack of personal contact with the teacher. From the 80 multiple-choice questions, the mean of correct answers was 45.5 , and of incorrect, 34.5 .

Conclusions: This study demonstrates that students can successfully learn with distance learning. It provides useful information for developing other Internet-based courses. The importance of this new tool for education in a large country like Brazil seems clear.

DESCRIPTORS: Medical education. Internet. Distance learning. Aesthetics. Laser.

The rapidly changing world of computer and information technology will bring dramatic changes to medicine in the $21^{\text {st }}$ century ${ }^{1}$. The Internet expands the range and flexibility of teaching options available for health sciences, and it enhances the ability to process the ever-increasing volume of medical knowledge. The advantages of teaching health sciences using the Internet include enhanced convenience, novelty, and interactivity, which lead to the possibility of expanding knowledge $^{2}$. The multiple resources provided by the Internet offer a new and excit- ing environment that will improve patient care, education, and research ${ }^{3}$. The Internet can be used to establish the network, while medical schools should collaborate to improve educational programs and evaluation meth$\mathrm{ods}^{4}$. Training programs involving medical students at geographically separate sites are also possible with the Internet $^{5,6}$.

A most interesting alternative for

From the Plastic Surgery Division, Hospital das Clínicas, Faculty of Medicine, University of São Paulo. the use of the Internet is the substitution of a virtual model for the traditional teacher-student pattern in the classroom.

In 2000 we proposed the opening of an Internet-based course that covered the same basic topics in plastic surgery as a traditionally taught course that is offered to the students in the initial years of medical training; the proposal was accepted.

This course attracted a surprising number of students. In this article, we describe our experience with the online method and our evaluation of it. 


\section{METHODS}

From October $1^{\text {st }}$ to October $30^{\text {th }}$ 2000, a course named Aesthetic Medicine and Laser Surgery was implemented, with basic and clinical topics divided into 20 virtual lessons that were available on the Plastic Surgery's Web site 24 hours a day, seven days a week. The virtual lessons were all linked with hypertext, so students could progress through the topics in any sequence they wanted. E-mail was used for feedback and problem solving.

At the end of the course, 5 credits were granted to the students, as established by the University for mastering this material.

The staff of this course was composed of 4 people: a supervisor, a tutor, a system manager, and a secretary. The supervisor was responsible for the selection of modules and themes, distribution of tasks, and the final revision. The tutor was responsible for the selection of themes, composing the test and questionnaires, researching of scientific material, development of virtual lessons, and the final revision. The system manager produced the Web site and adapted the course materials for publication on the Web. The secretary corrected and formatted the texts, questionnaires, and the evaluation test, and organized statistical data and references.

From the 69 students enrolled, 63 were medical students from the first to the third year; 5 were audiology students from the third year and one was a second-year nursing student. Students were asked to answer two questionnaires, given on the first and on the last day of the course. A multiplechoice evaluation was also given on the last day to assess the acquired knowledge on basic and clinical topics.

The pre-course multiple-choice questionnaire focused on the following aspects regarding the students: (a) why they chose the course; (b) why they were interested in an Internet-based course; (c) what expectations they had when taking this course; (d) whether they had a private computer; (e) their frequency of Internet access; (f) their computer skills, and (g) the configuration of their computer.

The post-course questionnaire (multiple choice and open questions) was administered on the last day of the course; it asked students to evaluate the following aspects: (a) the frequency of Web site visits; (b) the time they remained connected; (c) whether they had difficulty accessing the site; (d) the quality of the basic and clinical material; (e) whether they followed a standard sequence of study; (f) whether they printed the material to study; $(\mathrm{g})$ whether they could learn only by reading on the computer screen; (h) what percentage of theory should be included in a course via Internet; (i) whether they enjoyed this Internetbased course, and (j) whether they would enroll for another Internet-based course. Two open-ended questions asked about the positive and negative aspects of this course.

The evaluation test had 80 multiple-choice questions with 5 answering options. One wrong answer would cancel one correct answer. The student could mark the last option, which meant I don't know, and would not be punished by this choice.

\section{RESULTS}

\section{PRE-COURSE QUESTIONNAIRE}

Answers to the first questionnaire revealed that the students opted for this course, instead of any of the others (such as those offered as optional in the training course) mainly because of the topic - aesthetic medicine and laser surgery (59\%); the fact of being via Internet $(28 \%)$, and because credits were given (13\%). Their interest in an Internet-based course in general is described in table 1. Students' expectations as related to an Internet course were: to have more free time (37\%), to become familiar with distance learning (33\%), and to learn the basis of aesthetic medicine and laser surgery (30\%).

Table 1 - Students' interest for a course via Internet $(n=69)$.

\begin{tabular}{lc}
\hline Arguments & Students \\
\hline Learning at any time & $67 \%$ \\
Studying at home & $17 \%$ \\
Trying out a non-traditional method & $9 \%$ \\
Dislike for traditional methods & $5 \%$ \\
Better than traditional teaching & $2 \%$ \\
\hline
\end{tabular}

Ninety-four percent of the students had a computer at home, and they considered their computer skills as excellent $(7 \%)$, very good $(15 \%)$, good $(42 \%)$, satisfactory $(33 \%)$, or none (3\%). Their computer configurations were: Pentium I (35\%), Pentium II (22\%), Pentium III (26\%), AMD $(10 \%)$, and Celleron $(7 \%)$. The frequency of Internet visits before this course is shown in table 2 .

Table 2 - Frequency with usual Internet activity before the course.

\begin{tabular}{lc}
\hline Frequency & Percentage \\
\hline Daily & $48 \%$ \\
2 or 3 times a week & $12 \%$ \\
Once a week & $28 \%$ \\
Once a month & $12 \%$ \\
Never & $0 \%$ \\
\hline
\end{tabular}

\section{POST-COURSE QUESTIONNAIRE}

The second questionnaire revealed that visits to the Web site for the course were made mainly during the weekends $(35 \%)$. Twenty-eight percent of the students visited from 1 to 3 times 
a week, and $8 \%$ visited more than 3 times a week. Twenty-nine percent visited only on the last week before the test. None visited daily.

The time the students remained connected was: more than 2 hours $(49 \%)$, less than one hour $(31 \%)$, or variable $(20 \%)$. The period of the day they visited the Web site was: $8 \%$ in the morning, $14 \%$ in the afternoon, $39 \%$ at night, and $39 \%$ at variable times. Only $18 \%$ had technical difficulties accessing the Web site.

According to the students, the quality of the basic and clinical material provided on the site can be seen on table 3 . Sixty-seven percent of the students started with the basic topics, while $18 \%$ followed no specific sequence. Ninetytwo percent did not print the material to study. Thirty-one percent reported that they could learn from the computer screen as well they could from printed material, $32 \%$ found some difficulties with reading from a computer screen, $28 \%$ took only a little advantage of this method, while $9 \%$ learned nothing at all. Their answers concerning the percentage of theory that should be given via Internet are shown in table 4 . When

Table 3 - Students' evaluation of the basic and clinical material provided on the course Web site.

\begin{tabular}{lcc}
\hline GRADE & BASIC & CLINICAL \\
\hline Excellent & $15 \%$ & $14 \%$ \\
Good & $36 \%$ & $40 \%$ \\
Satisfactory & $38 \%$ & $32 \%$ \\
Poor & $6 \%$ & $3 \%$ \\
Not enough & $5 \%$ & $1 \%$ \\
\hline
\end{tabular}

Table 4 - Students' opinion about the proportion of theory that a course should give via Internet.

\begin{tabular}{ll}
\hline Proportion & Students \\
\hline Up to $15 \%$ & $12 \%$ \\
Up to $30 \%$ & $15 \%$ \\
Up to $50 \%$ & $29 \%$ \\
Up to $75 \%$ & $15 \%$ \\
Up to $100 \%$ & $29 \%$ \\
\hline
\end{tabular}

asked if they enjoyed the experience with an Internet-based course, $89 \%$ were affirmative and $88 \%$ said they would enroll for another course via the Internet.

The positive and negative aspects of this kind of course are described in table 5 and 6 , respectively.

Table 5 - Positive aspects of this virtual course.

\begin{tabular}{lc}
\hline Aspects & $\begin{array}{c}\text { Number of } \\
\text { Students }\end{array}$ \\
\hline Freedom of schedule & 47 \\
Possibility to choose the way to study & 11 \\
Comfort of studying at home & 11 \\
Free time for other activities & 05 \\
Easy material & 05 \\
Lack of failure due to absence & 01 \\
\hline
\end{tabular}

Table 6 - Negative aspects of this virtual course.

\begin{tabular}{lc}
\hline Aspects & $\begin{array}{c}\text { Number of } \\
\text { Students }\end{array}$ \\
& \\
\hline Lack of contact with the teacher & 27 \\
Keeps the telephone line busy & 15 \\
Lack of exercises & 14 \\
Problems with connection & 09 \\
Tendency to lose concentration & 07 \\
Printing not possible & 07 \\
Lack of a CD ROM with the material & 01 \\
\hline
\end{tabular}

\section{TEST}

The time spent on the test ranged from 20 to 90 minutes $($ mean $=49$ $\mathrm{min})$. The number of correct answers ranged from 14 to 62 (mean $=45.5)$; incorrect answers ranged from 18 to 66 (mean = 34.5), and the "I don't know" option ranged from 3 to 56 (mean = 19).

\section{DISCUSSION}

The Internet has tremendous potential for students and teachers because it is an accessible place for information. With the availability of online resources, anyone can reach data, people, and ideas anytime and can search any area of knowledge deeply and thoroughly. Some of these new learning tools will provide incredible opportunities for expanding knowledge and may even change the way people read, think, and learn ${ }^{7}$. Because of the potential opportunities presented by this innovative method of learning, we decided to test it with medical students.

This Internet course was designed based on an integration of hypertext and rule-based knowledge ${ }^{8}$. Course evaluation is essential for continuous enhancement of teaching, and it can be done through questionnaires ${ }^{9}$. The first questionnaire showed that students' major interest in taking an Internetbased course was the freedom to choose the time to study and to attend a course at home. Having more free time had the same value for students as becoming familiar with distance learning and the course theme itself, perhaps indicating a need for more free time within the medical training schedule.

Almost all students had private modern computers, had satisfactory or good computer skills, and were used to accessing Internet sites daily. Technically speaking, these characteristics would facilitate any Internet-based course. In contrast to our students, another medical school noted that only $53 \%$ of the students had used Internet before the course, and the course was a way to get acquainted with the Internet for the first time ${ }^{10}$.

The post-course questionnaire revealed the way students managed their time with the course. Not surprisingly, they did not use the time specified by the University to attend this course. Rather, their visits were during the weekends and on the last week before the test, mainly at night, which might suggest a need for free time for other activities.

Hypertext-linked keywords help the students learn the subjects, and a teacher can evaluate student learning 
by e-mail or multiple-choice test ${ }^{11}$. Although we provided material that was completely accessible in any order through hyperlinks, students tended to follow a traditional sequence of study, which may suggest that they should be taught new ways of acquiring knowledge. E-mail was not used as expected, which might indicate that they are still not familiar with this approach to problem solving and feedback. Our results indicate that some of the students could learn directly from the screen, just as well as from printed material. This ability to learn from the computer screen might revolutionize teaching methods and solve the distressing problem of the enormous quantity of scientific papers produced almost daily on a specific subject. We are in agreement with Bell et al. ${ }^{12}$ when they stated that online tutorials may produce greater learning efficiency and satisfaction than printed materials do, but one exposure may be insufficient for longterm knowledge retention, and instructional features that produce greater long-term retention of learning are needed.
The test was in a multiple-choice format with an option - I don't know - that would not invalidate any correct answer. We believed that this method of evaluation, which students had used in traditional classrooms, would minimize guessing and cheating. In this way, we hoped to have an objective idea about what students had really learned. Results indicated successful outcomes in student learning, as has been mentioned by other authors ${ }^{13}$.

The vast majority of students enjoyed the experience with the Internet and would enroll for another Internetbased course, which demonstrates that they are open to new methods of learning. Freedom of scheduling was doubtlessly the most positive aspect reported, and the lack of personal contact with the teacher the most negative aspect reported, showing that the non-virtual presence of a teacher is still important during training. Other problems, such as tying up the telephone line, lack of oriented exercises, and tendency for losing concentration by some students, led to the conclusion that challenges and pit- falls will arise, and implementation of online instructional technologies in medical education requires an appreciation of the medium's heterogeneous nature, its strengths, weaknesses, and limitations ${ }^{14}$.

This study shows that it is quite possible to continue with distance learning in this medical school. It must be stressed that any medical school and teaching hospital can use information technology and the Internet in the coming decade to improve individual education in medical training courses. Distance learning may offer powerful and clever solutions for both students and teachers living in different cities.

\section{ACKNOWLEDGEMENTS}

The authors thank the system manager Marcelo Ferreira de Araújo and the secretary Liliann Cristina Amoroso for their excellent technical assistance without which this Internet-based course would not have been accomplished.
MAIO M de e col. - Experiência obtida com o primeiro curso baseado na Internet na Faculdade de Medicina, Universidade de São Paulo. Rev. Hosp. Clín. Fac. Med. S. Paulo 56(3):69-74, 2001.
Objetivo: A Internet possibilita variedade e flexibilidade de métodos de ensino, mostrando-se eficiente diante do crescente volume de conhecimentos na área médica. O propósito deste estudo foi descrever e discutir a experi- ência obtida de uma disciplina médica tradicional de graduação, transformada em disciplina baseada na Internet.

Métodos: Sessenta e nove estudantes participaram do curso de um mês de duração, ao final do qual foram sub- 
metidos a 80 questões de múltipla escolha para avaliar os conhecimentos adquiridos e a questionários antes e ao final do curso.

Resultados: A maioria dos alunos optou por este curso pela liberdade de escolha de horário de estudo (67\%). A grande maioria (94\%) possuía computador em casa e usava a Internet com frequiência $(75 \%)$ anteriormente à disciplina. Durante o curso, as visitas foram realizadas durante os finais de semana $(35 \%)$ e na última semana antes da prova (29\%). Alguns estudantes (31\%) referiram capacidade de aprendizado apenas com leitura na tela do computador sem a necessidade de material impresso. Oitenta e nove por cento dos mesmos gostaram da experiência deste tipo de disciplina e $88 \%$ responderam que fariam outra disciplina via Internet. $\mathrm{O}$ aspecto positivo principal foi da liberdade de horários e o negativo da falta de contato com o Professor. Do teste de múltipla escolha, a média das questões corretas foi de 45,5 e a média das ques- tões erradas foi de 34,5 .

Conclusão: Este estudo demonstra real possibilidade de ensino de graduação à distância, além de fornecer informações básicas para outras disciplinas via Internet. $\mathrm{O}$ potencial para este tipo de educação em países como o Brazil com território amplo parece grande.

DESCRITORES: Educação Médica. Internet. Educação à distância. Estética. Laser.

\section{REFERENCES}

1. PAPERNY DM - Computers and information technology: implications for the 21st century. Adolesc Med 2000;11(1):183202.

2. FOTHERINGHAM MJ, OWIES D, LESLIE E et al.- Interactive health communication in preventive medicine: Internet-based strategies in teaching and research. Am J Prev Med 2000;19(2):113-120.

3. STECKNER K \& BORKOWSKI R - On-line resources for the pain medicine physician. Reg Anesth Pain Med 2000;25(3):291-295.
4. GARR DR, LACKLAND DT \& WILSON DB - Prevention education and evaluation in U.S. medical school: a status report. Acad Med 2000;75:S14-21.

5. SIMPSON A, WEIST A, READING NG et al. - A pilot Internet teaching project to support specialist medical training. Hosp Med 1999;60(12):904-907.

6. WELCH PG - The Walter Reed Army Medical Center Nephrology Service website: a tool for military-wide provider and patient education. Mil Med 2000;165(3):189-192. 
7. DEDE C - The evolution of constructivist learning environments: Immersion is distributed, virtual worlds. Educ Technol 1995;35(5):46-52.

8. EKDAHL C, KARLSSON D, WIGERTZ et al. - A study of the usage of a decision-support system for infective endocarditis. Med Inform Internet Med 2000; 25(1):1-18.

9. PITERMAN L \& MCCALL L - Distance education. Part 7. Evaluation of the Graduate Diploma of Family Medicine. Does a distance education course for GPs influence their report clinical and professional practice? Aust Fam Physician 2000;29:38-42.

10. MOURA AA, LHANO MG \& DEL GIGLIO A - Educação via Internet: experiência preliminar de Hematologia e Oncologia da Faculdade de Medicina da Fundação ABC. Rev Assoc Med Bras 2000;46(1):47-51.
11. CANALS ML - New methods of seafarer's training: an Internet "refresher course on first-aid and medical care on board". Int Marit Health 1999; 50(1-4):15-21.

12. BELL DS, FONAROW GC, HAYS RD et al.- Self-study from webbased and printed guideline materials. A randomized, controlled trial among resident physicians. Ann Intern Med 2000; 132(12):938-946

13. COX CG, WHITE D, BRINSON H et al. - Distance learning: health education for ninth-grade students. J Telemed Telecare 2000;6:S8-10.

14. PEREIRA J, PEDEN \& CAMPBELL K - Instructional technology in medical education: lessons learnt. J Telemed Telecare 2000;6 Suppl 2:S56-58.

Received for publication on February 16, 2001 